\title{
PELATIHAN PEMASANGAN INSTALASI LISTRIK RUMAH TANGGA YANG AMAN BAGI WARGA KELURAHAN PAGUTAN BARAT KOTA MATARAM
}

\author{
Ni Made Seniari ${ }^{*}$ ), Supriyatna, Abdul Natsir, Ida Ayu Sri Adnyani, Sabar Nababan \\ Jurusan Teknik Elektro, Fakultas Teknik, Universitas Mataram \\ Jl. Majapahit 62, Mataram 83125, Lombok - Indonesia \\ *alamat korespondensi : seniari_nimade@unram.ac.id
}

\begin{abstract}
ABSTRAK
Listrik merupakan bagian penting dalam kehidupan manusia. Kebutuhan energi listrik meningkat secara linier dengan adanya peningkatan pertumbuhan penduduk. Hal ini disebabkan oleh karena sebagian besar aktivitas manusia yang dilakukan sehari-hari membutuhkan sumber energi listrik. Energi listrik yang mempermudah kehidupan manusia terkadang bisa menimbulkan malapetaka. Beberapa kasus kebakaran disebabkan oleh konsleting listrik pada instalasinya. Hal ini diakibatkan oleh instalasi listrik yang tidak sesuai standard dan kurangnya pemahaman dan pengetahuan tentang kelistrikan pada masyarakat. Untuk itu perlu diupayakan tenaga professional di bidang pemasangan instalasi listrik, untuk menghindari bahaya yang di timbulkan, untuk kebutuhan pemasangan instalasi sendiri, dan juga untuk membuka lapangan kerja baru sebagai instalatir listrik. Kegiatan pengabdian kepada masyarakat ini bertujuan untuk melatih para remaja di Kelurahan Pagutan Barat untuk dapat melakukan pemasangan, perbaikan instalasi, dan bahkan sebagai modal keterampilan untuk membuka lapangan kerja sendiri. Kegiatan pengabdian kepada masyarakat (PKM) dilaksanakan dalam bentuk pelatihan dengan metode ceramah mengenai pengenalan alat dan bahan instalasi listrik, demo pemasangan dan pengawatan instalasi listrik sesuai standar PUIL serta praktek langsung dengan papan-papan modul yang telah disiapkan. Diharapkan peserta memahami dengan baik alat, bahan, tata tertib dan standar pemasangan instalasi listrik rumah tangga. Serta dapat memahami bahaya listrik dan cara mengamankannya. Disamping itu peserta pelatihan ditargetkan bisa membaca gambar instalasi, mengukur tegangan, mendeteksi sambungan yang putus, dan dapat membuat instalasi penerangan menggunakan berbagai macam sakelar dan stop kontak. Materi yang diberikan dalam pelatihan kegiatan kepada remaja ini sangat bermanfaat untuk menambah pengetahuan dan keterampilan dalam pemasangan instalasi listrik yang aman dan sesuai standar PUIL dapat di implementasikan untuk kepentingan pribadi, rumah tangga sendiri dan bahkan bisa di tingkatkan untuk membuka lapangan kerja sendiri.
\end{abstract}

Kata Kunci: instalasi listrik aman, Pagutan Barat, Mataram 


\section{PENDAHULUAN}

Kebutuhan akan tenaga listrik dari tahun ke tahun semakin meningkat seiring pertambahan jumlah penduduk. Kebutuhan akan pemasangan instalasi listrik juga semakin bertambah. Untuk menghindari bahaya kebakaran akibat instalasi listrik yang tidak sesuai standar maka masyarakat perlu di beri pengetahuan dan keterampilan dalam melakukan pemasangan instalasi listrik.

Pelatihan pemasangan instalasi listrik di berikan kepada pemuda di Kelurahan Pagutan Barat, mengingat Pagutan Barat adalah sebuah desa di tengah kota. Rata-rata pendidikan sederajat SMA dengan tingkat pendapatan yang masih di bawah standard dan kurang memiliki keterampilan paraktis untuk bersaing di dunia kerja.

Untuk itu pemuda Kelurahan Pagutan Barat secara umum, perlu di berikan ketrampilan praktis, salah satunya tentang memasang instalasi listrik rumah tangga yang aman sesuai standar PUIL, yang nantinya diharapkan dapat di gunakan untuk keperluan rumah tangganya sendiri, bisa dipakai untuk modal melamar kerja, dan bahkan bisa di pakai untuk membuka usaha baru atau membuka usaha alternative.

\section{METODE KEGIATAN}

Untuk memecahkan permasalah di atas, perlu diadakan kegiatan pengabdian kepada masyarakat pelatihan pemasangan instalasi listrik rumah tangga dengan beberapa tahap kegiatan sebagai berikut :

1. Persiapan peserta : Menginvetaris pemuda yang bersedia mengikuti pelatihan pemasangan instalasi listrik melalui kepala lingungan di wakili oleh beberapa pemuda.

2. Persiapan membuat gambar denah rumah, gambar rangkaian listrik dan pengawatan, dengan gambar denah perencanaan rumah typ 27 , 40 dan $120 \mathrm{~m} 2$.

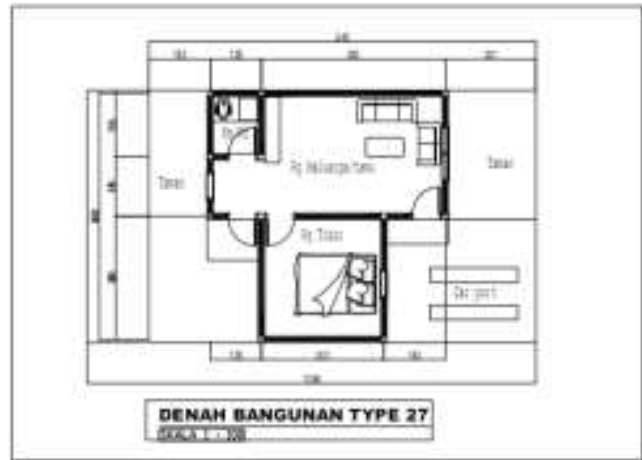

Gambar 1. Denah bangunan type 27 $\mathrm{m}^{2}$ 


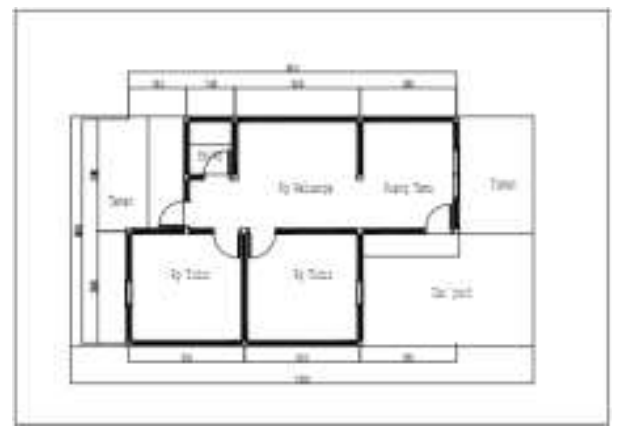

Gambar 2. Denah bangunan type 40 $\mathrm{m}^{2}$

3. Persiapan Papan Module, yaitu dengan menggunakan lembar triplek berkaki (sehingga modul mampu berdiri). Diawali dengan module rangkaian yang sangat sederhana yaitu pemasangan MCB, stop kontak untuk rangkaian seri dan pararel. Tahap berikutnya dilanjutkan dengan pemasangan pada module rumah sederhana type $27,40 \mathrm{~m} 2$ yang hanya terdiri dari satu group. Tahap berikutnya adalah rumah type $120 \mathrm{~m} 2$ yang terdiri dari 3 group.

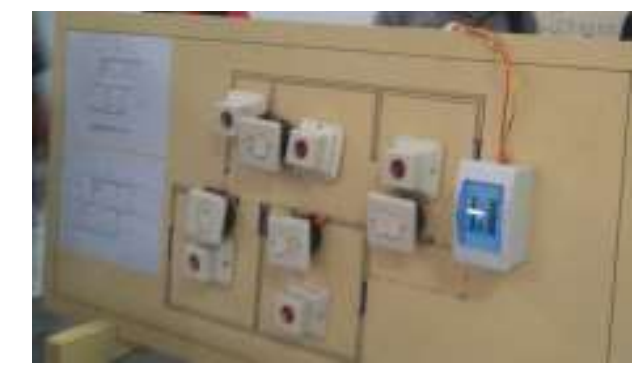

Gambar 3. Modul Demo instalasi listrik

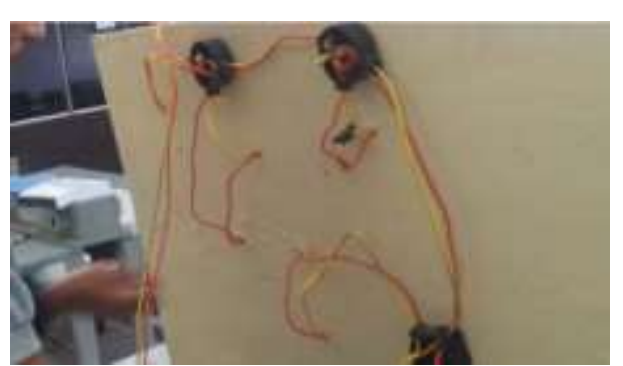

Gambar 4. Modul Demo pengawatan instalasi listrik.

4. Pemberian materi pelatihan yang di laksanakan di Laboratorium Listrik Dasar Fakultas Teknik Unram dengan metode ceramah tentang pengenalan alat dan bahan instalasi listrik, tata tertib dan standar pemasangan instalasi listrik, simbul dan membaca simbul komponen komponen instalasi. Kemudian di lanjutkan dengan demo pemasangan instalasi dengan papan module yang tersedia. Selanjutnya peserta mempraktekkan langsung pemasangan instalasi dengan papan modul, alat, bahan gambar denah yang telah disediakan.

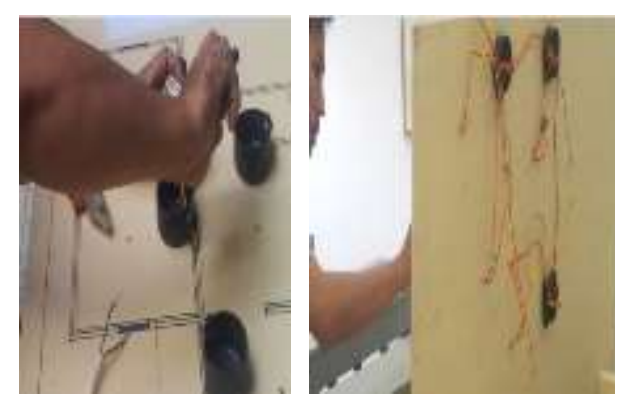

Gambar 5. Praktek instalasi listrik 


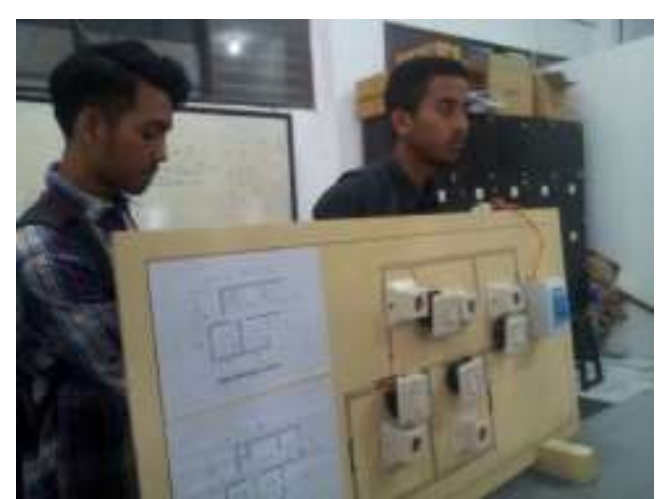

Gambar 6. Hasil praktek peserta pelatihan

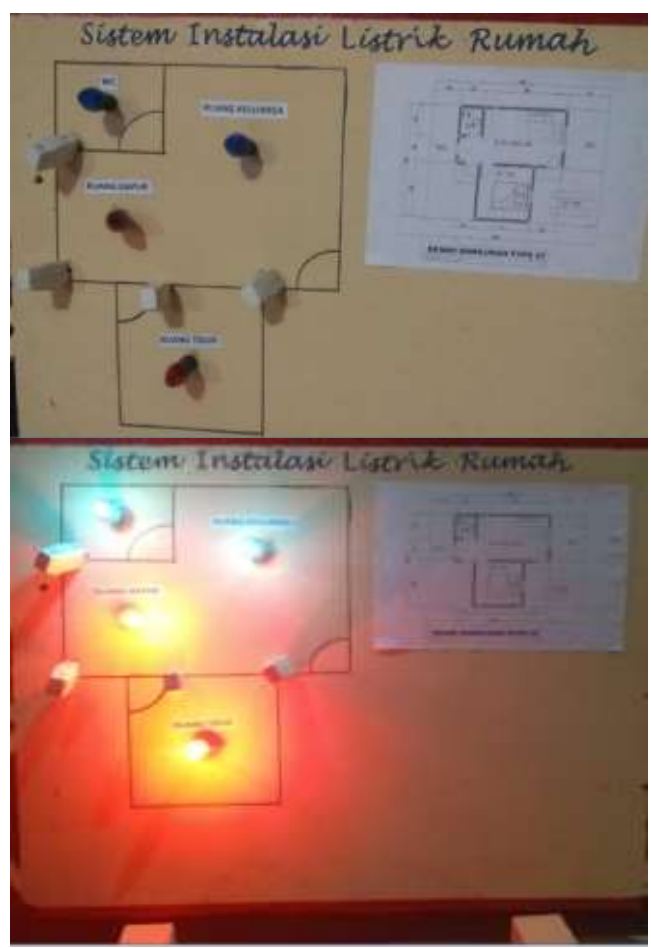

Gambar 7. Hasil Praktek peserta pelatihan

5. Tanya jawab dan evaluasi. Dilakukan pada penghujung tahapan kegiatan. Evaluasi kegiatan dilakukan dengan praktek pemasangan secara berkelompok, melihat kesigapan peserta mempersiapkan dan melakukan pengawatan pemasangan instalasi.

\section{Realisasi Pemecahan masalah} dengan jalan mengumpulkan beberapa pemuda dari berbagai lingkungan di Kelurahan Pagutan Barat di beri pembekalan materi teori instalasi listrik meliputi : bahan, pengawatan, standard dan keamanan instalasi listrik. Di beri pelatihan dengan demo dan praktek langsung melalui papan-papan module, dari yang paling sederhana sampe yang lebih kompleks. Sehingga peserta memiliki ketrampilan pemasangan instalasi listrik rumah tangga, lebih percaya diri, dan dapat lebih mudah menembus dunia kerja dan bahkan bisa membuka lapangan kerja mandiri.

Para peserta pelatihan memiliki ketrampilan tambahan, bisa mengenal alat, bahan dan peraturan-peraturan memasang instalasi listrik baik untuk keperluan di rumah tangga sendiri, bahkan untuk membuka lapangan kerja sendiri.

Sebagai keluarga besar Universitas Mataram, maka seorang dosen juga memiliki kewajiban dan tanggung jawab moral untuk 
memperkenalkan, menginformasikan masalah-masalah penting yang menyentuh kehidupan masyarakat, dan di wajibkan untuk berinteraksi dengan masyarakat luas secara berkesinambungan. Di samping itu juga seorang dosen dan mahasiswa teknik elektro berusaha memberikan manfaat dan menjadi pelayanan bagi masyarakat, dimulai dari hal-hal yang sederhana. Diharapkan kegiatan seperti ini memberi dampak positif bagi perkembangan dan kemajuan masyarakat dan Universitas Mataram umumnya dan Jurusan Teknik Elektro khususnya.

Evaluasi dilakukan dengan cara meminta masukan kepada para peserta pelatihan mengenai hal-hal yang perlu dan belum di sampaikan, hal-hal yang belum jelas dalam penyampaian, peralatan-peralatan pendukung yang belum lengkap ataupun materi-materi pelatihan yang perlu dikembangkan. Hal ini menjadi perbaikan untuk pelaksanaan pelatihan berikutnya.

\section{HASIL DAN PEMBAHASAN}

Kegiatan ini dilaksanakan untuk mencapai tujuan yg telah ditetapkan. Materi yang diberikan meliputi :
1. Alat instalasi listrik

2. Bahan instalasi listrik dan ke gunaannya

3. Peraturan-peraturan dalam pemasangan instalasi listrik berdasarkan Suhinal (2016)

4. Pengawatan komponen-komponen instalasi (Indra dan Kamil, 2011):

- Dari KWH ke MCB

- Dari MCB ke Saklar dan ke lampu.

- Dari Saklar tunggal untuk 2 dan tiga lampu sekaligus

- Sebuah lampu di layani dengan saklar ganda (saklar tukar).

Selanjutnya dipraktekkan secara langsung oleh para pemuda dengan aplikasi pada papan modul yaitu (Mulianan, 2012):

- Rangkaian beban seri

- Rangkaian beban seri dan pararel

- Rumah tipe 24, 40 m2 dengan satu group

- Rumah type 120 m2 dengan 3 group.

Kegiatan pelatihan yg dilaksanakan ada yang sesuai rencana dan ada yg tidak sesuai rencana. Yang sesuai rencana meliputi materi 
pelatihan dan modul-modul pelatihan. Yang tidak sesuai rencana meliputi waktu, tempat pelaksanaan dan jumlah peserta pelatihan. Tetapi secara umum pengabdian masyarakat ini dinilai effektif. Hal ini ditandai dengan adanya komunikasi yang baik antara peserta dengan penyaji materi dan dengan mahasiswa teknik elektro, dan komunikasi ini bersifat interaktif. Peserta mengutarakan banyak pertanyaan yang berkaitan dengan bahan, pemilihan bahan dan pemasangan instalasi.

Beberapa faktor pendukung kegiatan pengabdian meliputi : adanya ijin dan dukungan dari pihak aparat Kelurahan Pagutan Barat, antosias peserta mengikuti pelatihan, semangat dosen dan mahasiswa dalam membantu dan menyelenggarakan pelatihan. Lengkapnya peralatan dan bahan instalasi, lengkapannya modulmodul pelatihan dari yang paling sederhana sampe ke yang lebih kompleks.

Sedangkan faktor penghambat adalah sulitnya mencari waktu yang tepat untuk mengumpulkan peserta pelatihan, sulitnya mencari tempat 
listrik, sehingga hasil pelatihan ini dapat di ulang-ulang di rumah masing-masing sehingga ilmu dan keterampilan yang telah di dapat bisa dikembangkan dan di perdalam.

\section{UCAPAN TERIMAKASIH}

Ucapan terimakasi disampaikan kepada semua pihak yang ikut berperan aktif dalam pelaksanaan kegiatan pengabdian kepada masyarakat ini, khususnya kepada Dekan Fakultas Teknik Unram, Ketua LLPM Universitas Mataram, Kepala Lurah Desa Pagutan Barat, Kepala Lingkungan di Pagutan Barat, Peserta Pelatihan, Dosen-dosen dan mahasiswa JTE Unram yang terlibat dan ikut membantu pelaksanaan kegiatan pengabdian kepada masyarakat ini.

\section{DAFTAR PUSTAKA}

Indra., Z, dan Kamil, I., 2011. Analisis Sistem Instalasi Listrik Rumah Tinggal dan Gedung untuk Mencegah Bahaya Kebakaran". Jurnal IImiah Elite Elektro,Vol.2, No.1, Maret 2011:40-44

Mulianan, R.Y. 2012. Dasar-Dasar Instalasi Listrik. https://rohmatyusufmuliyana. wordpress.com/elektro/dasar-
\%E2\%80\%93-dasar-instalasilistrik/ Diakses 20-4-2018.

Suhinal, El. 2016. Instalasi Listrik Rumah Dengan Memahami Wiring Diagram. https://www.listrikpraktis.com/2016/01/belajarinstalasi-dasar-rumahmemahami- wiringdiagram.html. diakses 20-42018 